\title{
Source attributions of pollution to the Western Arctic during the NASA ARCTAS field campaign
}

\author{
H. Bian ${ }^{1,2}$, P. R. Colarco ${ }^{2}$, M. Chin ${ }^{2}$, G. Chen ${ }^{3}$, J. M. Rodriguez ${ }^{2}$, Q. Liang ${ }^{4,2}$, D. Blake ${ }^{5}$, D. A. Chu ${ }^{1,2}$, A. da Silva ${ }^{6}$,

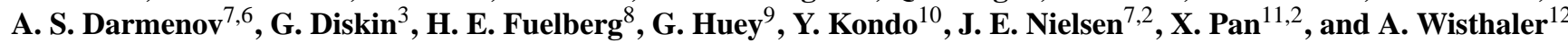 \\ ${ }^{1}$ Joint Center for Environmental Technology UMBC, Baltimore, MD, USA \\ ${ }^{2}$ Laboratory for Atmospheres, NASA Goddard Space Flight Center, Greenbelt, MD, USA \\ ${ }^{3}$ NASA Langley Research Center, Hampton, VA, USA \\ ${ }^{4}$ Universities Space Research Association, GESTAR, Columbia, MD, USA \\ ${ }^{5}$ Department of Chemistry, University of California, Irvine, CA, USA \\ ${ }^{6}$ Global Modeling and Assimilation Office, NASA Goddard Space Flight Center, Greenbelt, MD, USA \\ ${ }^{7}$ Science Systems and Applications Inc, Lanham, MD, USA \\ ${ }^{8}$ Department of Meteorology, Florida State University, Tallahassee, FL, USA \\ ${ }^{9}$ School of Earth and Atmospheric Sciences, Georgia Institute of Technology, Atlanta, GA, USA \\ ${ }^{10}$ Department of Earth and Planetary Science, University of Tokyo, Tokyo, Japan \\ ${ }^{11}$ School of Computer, Mathematical and Natural Sciences, Morgan State University, Baltimore, MD, USA \\ ${ }^{12}$ Institut für Ionenphysik, University of Innsbruck, Innsbruck, Austria
}

Correspondence to: H. Bian (huisheng.bian@ nasa.gov)

Received: 10 February 2012 - Published in Atmos. Chem. Phys. Discuss.: 5 April 2012

Revised: 27 March 2013 - Accepted: 16 April 2013 - Published: 7 May 2013

\begin{abstract}
We use the NASA GEOS-5 transport model with tagged tracers to investigate the contributions of different regional sources of $\mathrm{CO}$ and black carbon (BC) to their concentrations in the Western Arctic (i.e., 50-90 $\mathrm{N}$ and 190$320^{\circ} \mathrm{E}$ ) in spring and summer 2008. The model is evaluated by comparing the results with airborne measurements of $\mathrm{CO}$ and BC from the NASA Arctic Research of the Composition of the Troposphere from Aircraft and Satellites (ARCTAS) field campaigns to demonstrate the strengths and limitations of our simulations. We also examine the reliability of tagged $\mathrm{CO}$ tracers in characterizing air mass origins using the measured fossil fuel tracer of dichloromethane and the biomass burning tracer of acetonitrile. Our tagged CO simulations suggest that most of the enhanced $\mathrm{CO}$ concentrations (above background level from $\mathrm{CH}_{4}$ production) observed during April originate from Asian anthropogenic emissions. Boreal biomass burning emissions and Asian anthropogenic emissions are of similar importance in July domain wise, although the biomass burning $\mathrm{CO}$ fraction is much larger in the area of the ARCTAS field experiments. The fraction of $\mathrm{CO}$ from Asian anthropogenic emissions is larger in spring than
\end{abstract}

in summer. European sources make up no more than $10 \%$ of $\mathrm{CO}$ levels in the campaign domain during either period. Comparisons of $\mathrm{CO}$ concentrations along the flight tracks with regional averages from GEOS-5 show that the alongtrack measurements are representative of the concentrations within the large domain of the Western Arctic in April but not in July.

\section{Introduction}

Midlatitude pollutants, including short-lived species such as aerosols, are often transported to the Arctic (Barrie, 1986; Weber et al., 2003). A series of internationally coordinated Arctic field campaigns under the umbrella of Polar Study using Aircraft, Remote Sensing, Surface Measurements and Models, of Climate, Chemistry, Aerosols, and Transport (POLARCAT), e.g., Arctic Research of the Composition of the Troposphere from Aircraft and Satellites (ARCTAS) (Jacob et al., 2010), Aerosol, Radiation, and Cloud Processes affecting Arctic Climate (ARCPAC) (Brock et al., 2011), 
POLARCAT-France (Quennehen et al., 2011), POLARCATGRACE (Pommier et al., 2010), and Airborne Extensive Regional Observations in SIBeria (YAK-AEROSIB) (Paris et al., 2009), were conducted in 2008 to better understand the impact of pollution on the Arctic atmospheric composition and climate. Here we use observations from the NASA ARCTAS field campaigns including ARCTAS Phase-A, which was based in Fairbanks, Alaska, USA, in April and ARCTAS Phase-B (ARCTAS-B), which was based at Cold Lake, Alberta, Canada, in July to study the source attribution of pollutants transported to the Western Arctic.

Most of the pollution found in the Arctic air is from the midlatitudes, and a large fraction is attributable to anthropogenic emissions. It is necessary to quantify the sources of pollution and identify the transport pathways in order to develop effective control strategies. Previous studies identified European emissions as the main source of Arctic pollution (Barrie, 1986; Rahn, 1981; Raatz and Shaw, 1984; Quinn et al., 2007, 2008; Shaw 1995). Emissions from Europe have declined and anthropogenic activities in Asia have greatly increased in the past two decades (e.g., Streets et al., 2009). Recent investigations suggest that Asian pollution sources have become significant to Arctic pollution; their degree of importance is still being debated (Fisher et al., 2010; Koch and Hansen, 2005; Shindell et al., 2008; Singh et al., 2010; Stohl, 2006). The uncertainty of the origin of Arctic pollution is partly due to complicated pathways for transport of air from midlatitudes to the Arctic (Fuelberg et al., 2010) and partly due to the uncertainties in estimating emission amounts and types in different regions.

Based on the analysis of snow samples, Hegg et al. (2009) concluded that more than $90 \%$ of the black carbon (BC) deposited in the Arctic in spring is due to biomass burning, another important source of Arctic pollution. Fires from Russia, Eastern Europe, and Central Asia all have their imprints on the Arctic (Stohl et al., 2007; Warneke et al., 2009, 2010). However, unlike anthropogenic sources that are mostly from midlatitudes, local boreal forest fires occur in places much closer to or even within the Arctic Circle, making important contributions to the pollutant loading in the Arctic.

A series of ARCTAS-related studies were published recently to address the source contribution to the Western Arctic, particularly by anthropogenic and biomass burning impacts. By using trajectories, Harrigan et al. (2011) studied the mean transport characteristics in ARCTAS-A from anthropogenic emissions. A global chemistry and transport model GEOS-CHEM was used to interpret the ARCTAS-A measurements and to investigate the origin of carbon monoxide (CO) (Fisher et al., 2010), ammonium sulfate aerosols (Fisher et al., 2011), and black carbon (BC) and organic aerosol (Wang et al., 2011) in the Arctic during spring season. These studies indicated that Asian anthropogenic emissions and biomass burning are important sources for the Arctic spring pollution. Other studies used aircraft measurements to investigate pollution emissions, transport, atmo- spheric composition and chemistry, and spatial variations of pollutants (Cubison et al., 2011; Hecobian et al., 2011; Kondo et al., 2011a; Liang et al., 2011; Matsui et al., 2011a, b; McNaughton et al., 2011; Shinozuka, 2011; Shinozuka et al., 2011; Singh et al., 2010). To date there has been no modeling study exploring source attribution for the Western Arctic during both the ARCTAS-A and ARCTAS-B periods with an integrated analysis of $\mathrm{CO}$ and aerosols. Our work addresses this shortcoming.

This study focuses on assessing the impact of long-range transport of midlatitude anthropogenic pollution and boreal forest fire emissions, both local and remote, on the Western Arctic atmospheric composition during both ARCTASA and ARCTAS-B. We use the NASA Goddard Earth Observing System model version 5 (GEOS-5) simulations with tagged CO from different source regions and source types (Bian et al., 2010) to quantify the contributions of continental sources and biomass burning to Arctic regional pollution. Model-simulated concentrations are evaluated and constrained by aircraft observations, and the tagged $\mathrm{CO}$ for air mass origin identification is compared with the observed anthropogenic tracer dichloromethane $\left(\mathrm{CH}_{2} \mathrm{Cl}_{2}\right)$ (Moore et al., $2004)$ and the biomass burning tracer acetonitrile $\left(\mathrm{CH}_{3} \mathrm{CN}\right)$ (Gouw et al., 2003; Li et al., 2003; Singh et al., 2003). The model is then used for source attribution for the entire Western Arctic domain to put the ARCTAS measurements into a regional context.

Carbon monoxide is emitted from both anthropogenic and biomass burning sources. It is not subject to dry and wet removal processes but can be oxidized by reaction with the hydroxyl radical $(\mathrm{OH})$. The lifetime of tropospheric $\mathrm{CO}$ is on the order of months (e.g., Pan et al., 1995), making it a good tracer for long-range transport. Black carbon, an important agent in Arctic climate change (Flanner et al., 2007), has similar sources as $\mathrm{CO}$ but a much shorter lifetime (about a week) because it can be removed by dry and wet depositions (Koch and Hansen, 2005). The relative abundance of CO and $\mathrm{BC}$ indicates the age of the air mass in the Arctic.

We describe the NASA DC- 8 measurements and NASA GEOS-5 model simulations during the ARCTAS period in Sect. 2. We evaluate the GEOS-5 model simulations using ARCTAS measurements in Sect. 3. In Sect. 4 we use GEOS5 simulations to investigate sources, transport, and transformation of Arctic pollutants during the ARCTAS periods. Conclusions and discussions are given in Sect. 5.

\section{Aircraft observations and GEOS-5 model}

\subsection{CO and BC concentrations from aircraft measurements}

The measurements of $\mathrm{CO}, \mathrm{BC}, \mathrm{CH}_{2} \mathrm{Cl}_{2}$, and $\mathrm{CH}_{3} \mathrm{CN}$ from the NASA DC-8 aircraft (http://www-air.larc.nasa.gov/ cgi-bin/arcstat-c) are used to evaluate the model simulation. 
There were 11 flights in March-April 2008 over Alaska and 7 flights in July over Canada. CO was measured using tunable diode laser absorption spectroscopy (TDLAS), which provides fast-response $(\sim 1 \mathrm{~s})$ and high-precision $( \pm 1$ parts per billion by volume) measurements (Diskin et al., 2002; Sachse et al., 1987). Fast-response aircraft data were averaged to $1 \mathrm{~min}$ intervals along the flight tracks (http://www-air.larc. nasa.gov/cgi-bin/arcstat-c). Aerosol BC was measured using a Single Particle Soot Photometer (SP2) based on laserinduced incandescence (LII) (Kondo et al., 2011b; Moteki and Kondo, 2007). The absolute accuracy of the BC measurements is estimated to be $\sim 10 \%$ (Kondo et al., 2011a). The SP2 measures individual BC particles with a time resolution of 1-5 min depending on aerosol concentration. Whole air canister samples were used for analysis of dozens of volatile organic compounds, one of which was $\mathrm{CH}_{2} \mathrm{Cl}_{2}$. Upon return to the laboratory, the canisters were assayed for $\mathrm{CH} 2 \mathrm{Cl} 2$ by electron capture detection and mass spectrometry. The accuracy of the measurement is $+10 \%$ and the measurement precision was $+10 \%$ (Colman et al., 2001). $\mathrm{CH}_{3} \mathrm{CN}$ was measured by proton-transfer-reaction mass spectrometry (PTRMS; Wisthaler et al., 2002). The precision of the 1 min average data used for the analysis presented herein is $\pm 25 \%$ at 100 ppt.

\subsection{Model description}

GEOS-5 is a global Earth system model, containing components for atmospheric circulation and composition, ocean circulation and biogeochemistry, land surface processes, and data assimilation (Rienecker et al., 2008). The model has 72 hybrid vertical sigma levels which are terrain following near the surface and transition to pressure levels above about $100 \mathrm{hPa}$ with a model top at $0.01 \mathrm{hPa}$ (about $85 \mathrm{~km}$ ). The model was run at $0.5^{\circ} \times 0.625^{\circ}$ latitude $\times$ longitude horizontal resolution. The model is "replayed" from the ModernEra Retrospective Analysis for Research and Applications (MERRA) meteorological analyses at the same spatial resolution produced by the NASA Global Modeling and Assimilation Office (Rienecker et al., 2011). Every $6 \mathrm{~h}$ the model dynamical state (winds, pressure, temperature, and humidity) is set to the balanced state provided by MERRA and then a $6 \mathrm{~h}$ forecast is performed until the next analysis is available.

A version of the Goddard Chemistry, Aerosol, Radiation, and Transport model (GOCART; Chin et al., 2002; Mian Chin et al., 2009) was implemented in GEOS-5 and used to simulate processes of sources, sinks, transport, and transformation for $\mathrm{CO}, \mathrm{SO}_{2}$, and aerosols within the GEOS-5 system. A description of the aerosol simulation in a previous version of the GEOS modeling system (GEOS-4) was provided in Colarco et al. (2010). GOCART aerosols included dust, sea salt, sulfate, black carbon, and organic matter, mixed externally (non-interacting). In this study GOCART CO was decomposed into five tagged CO tracers, each designed to track an important emission type or loca-
Table 1. Lifetime (days) of BC against dry, wet, and total depositions and the contribution of wet deposition to the total deposition.

\begin{tabular}{lllll}
\hline \multicolumn{3}{c}{ Lifetime (days) against } & $\begin{array}{l}\text { Wet dep. } \\
\text { contribution (\%) }\end{array}$ \\
\hline & Dry dep. & Wet dep. & Total dep. \\
April & 24 & 7.2 & 5.5 & $77 \%$ \\
July & 29 & 7.7 & 6.1 & $79 \%$ \\
\hline
\end{tabular}

tion (Bian et al., 2010; Fisher et al., 2010; Fuelberg et al., 2010; Stohl, 2006). The regions of the five CO source types are shown in Fig. 1a. The five $\mathrm{CO}$ sources include three anthropogenic sources from North America (NAFF or F1, yellow), Asia (ASFF or F2, orange), and Europe (EUFF or F3, green) and two biomass burning emission sources from nonboreal regions (NBBB or B1, blue-shaded area) and boreal regions (BOBB or B2, non-blue-shaded area). Figure $1 \mathrm{~b}-\mathrm{c}$ shows the DC-8 flight tracks for all flights during ARCTASA and ARCTAS-B, respectively.

Two chemical reactions are included in the $\mathrm{CO}$ simulation: chemical loss of $\mathrm{CO}$ via reaction with $\mathrm{OH}$, and chemical production of $\mathrm{CO}$ from $\mathrm{CH}_{4}$ oxidation by $\mathrm{OH}$. $\mathrm{CO}$ produced from non-methane hydrocarbon oxidation is parameterized as a direct emission (Bian et al., 2007). The $\mathrm{OH}$ field is prescribed using the results from a global chemistry and transport model simulation, the Global Modeling Initiative (GMI). The $\mathrm{CH}_{4}$ field is prescribed also from GMI based on the measurements at the worldwide NOAA Global Monitoring Division (GMD) sites and distributed as a function of latitude (Bian et al., 2007).

Black carbon is emitted as $80 \%$ hydrophobic and $20 \%$ hydrophilic (Liousse et al., 1996; Chin et al., 2002). During the "aging" process, the hydrophobic $\mathrm{BC}$ is converted to the hydrophilic phase with an e-folding time of 1.1 to 2.5 days (Cooke et al., 1999; Wang et al., 2011; Maria et al., 2004). The hydrophilic BC is subject to wet scavenging that accounts for the scavenging in convective updrafts and rainout/washout in large-scale precipitation (Giorgi and Cameides, 1986; Balkanski et al., 1993). The wet scavenging coefficient of hydrophilic BC is set to be 0.4. Dry deposition of $\mathrm{BC}$ is calculated by a resistance-in-series scheme (Wesely, 1989).

We computed the GEOS-5 global lifetimes of BC against dry and wet deposition for April and July 2008 (Table 1). The lifetime of BC is 5.5 days in April and 6.1 days in July, which is comparable to the annual mean value from the GEOSChem model for the same year (5.9 days, Wang et al., 2010). Wet deposition contributes $77 \%$ and $79 \%$ to total removal of $\mathrm{BC}$ in April and July, respectively - also close to the annual average value from GEOS-Chem (77\%, Wang et al., 2010). 
Table 2. Global and regional emissions of CO and BC in April and July 2008.

\begin{tabular}{|c|c|c|c|c|}
\hline & \multicolumn{2}{|c|}{$\mathrm{CO}\left(\mathrm{TgCO} \mathrm{mon}^{-1}\right)$} & \multicolumn{2}{|c|}{$\mathrm{BC}\left(\mathrm{TgC} \mathrm{mon}^{-1}\right)$} \\
\hline & April & July & April & July \\
\hline Anthropogenic & $57.7^{\mathrm{a}}(51 / 59)^{\mathrm{b}}$ & 59.6 & 0.45 & 0.47 \\
\hline NAFF (F1) & 7.3 & 7.6 & 0.032 & 0.033 \\
\hline ASFF (F2) & 28.8 & 29.7 & 0.25 & 0.26 \\
\hline EUFF (F3) & 5.4 & 5.6 & 0.046 & 0.047 \\
\hline Secondary production from NMHC oxidation ${ }^{\mathrm{c}}$ & $9.7(8.1 / 9.4)$ & 9.9 & & \\
\hline Open fires & $43.6(104 / 50)$ & 46.1 & 0.63 & 0.48 \\
\hline NBBB (B1) & 19.6 & 33.5 & 0.30 & 0.42 \\
\hline BOBB (B2) & 19.7 & 8.0 & 0.33 & 0.060 \\
\hline Secondary production from NMHC oxidation ${ }^{\mathrm{d}}$ & $4.3(10 / 4.9)$ & 4.6 & & \\
\hline Biogenic & $21.9(29 / 29)$ & 36.3 & & \\
\hline Methane & $67(71 / 71)$ & 75 & & \\
\hline Ship & & & 0.0049 & 0.0050 \\
\hline Total & $190(255 / 209)$ & 217 & 1.1 & 0.95 \\
\hline
\end{tabular}

\subsection{Emissions of $\mathrm{CO}$ and $\mathrm{BC}$}

The emissions for the $\mathrm{CO}$ and aerosol simulations are as described in Bian et al. (2007) and Colarco et al. (2010), except as updated here. Anthropogenic emissions of $\mathrm{CO}$ are adopted from the Emission Database for Global Atmospheric Research (EDGAR) 2000, overwritten regionally by Environmental Protection Agency (EPA) 1999 National Emission Inventory over USA, European Monitoring and Evaluation Programme (EMEP) over Europe, Big Bend Regional Aerosol and Visibility Observational (BRAVO) over northern Mexico, Streets 2000 over Southeast Asia, and Streets 2001 over China (Yuan et al., 2012). Anthropogenic emissions of BC (including ship and aircraft emissions) are from the compilation of A2-MAP emission that is available for global model simulations (Diehl et al., 2012), such as models in the international project of Aerosol Comparisons between Observations and Models (AeroCom). The biogenic source of $\mathrm{CO}$ is prescribed based on results from the Global Modeling Initiative (GMI) global chemistry and transport model, which uses the Model of Emissions of Gases and Aerosols from Nature (MEGAN, Guenther et al., 2006) for biogenic emissions of non-methane hydrocarbon (NMHC) as a $\mathrm{CO}$ source. CO from methane oxidation is included as well (details in Bian et al., 2007).

Biomass burning emissions of $\mathrm{CO}$ and $\mathrm{BC}$ are from the Quick Fire Emission Dataset (QFED) version 2.4. The QFED emissions are based on the fire radiative power (top-down) approach to derive the amount of combusted biomass (i.e., dry mass burned or DM) by calibrating initially against global monthly mean emissions of Global Fire Emission Database (GFED) version 2 (Darmenov and da Silva, 2013;
Petrenko et al., 2012). The fire radiative power (FRP) and location of the fires are obtained from the Moderate Resolution Imaging Spectroradiometer (MODIS) Level 2 fire products (MOD14 and MYD14) and the MODIS Geolocation products (MOD03 and MYD03). Species-specific emission factors are then applied to DM estimates to obtain tracer gas and aerosol emissions. For aerosol species, the QFED emissions are further calibrated by employing biome-dependent enhancing factors based on the constraint on model AOT with MODIS AOT for four biomes under our current assumptions of particle properties (size and refractive index, and hence mass extinction efficiency, MEE). For example, the enhancement factors of $\mathrm{BC}$ are ranging from 1.8 (tropical biome) to 4.5 (extra-tropical biome).

Table 2 summarizes the emissions of $\mathrm{CO}$ and $\mathrm{BC}$ over the globe and in the five tagged region domains. Most of the $\mathrm{CO}$ is emitted from anthropogenic and biomass burning sources, with anthropogenic emissions being about $30 \%$ higher than biomass burning. Regionally, the important emissions are anthropogenic emission from Asia (ASFF) and biomass burning emissions from mid to high latitudes in the Northern Hemisphere (NH) (BOBB) in both months. Further analysis indicates that high BOBB occurs primarily over Russia/Kazakhstan in April and over North America in July. $\mathrm{CO}$ emission in July is higher than in April by $15 \%$ in total. Fisher et al. (2010) studied CO over the Arctic during ARCTAS-A using the GEOS-CHEM model. When compared to ARCTAS-A observations, they found that their sources needed to be adjusted to optimize the agreement with the observations. The GEOS-5 CO emissions are comparable 


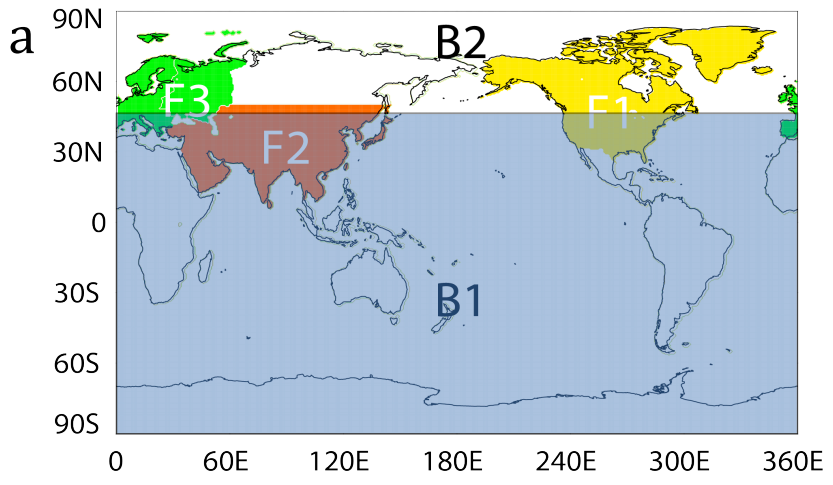

b

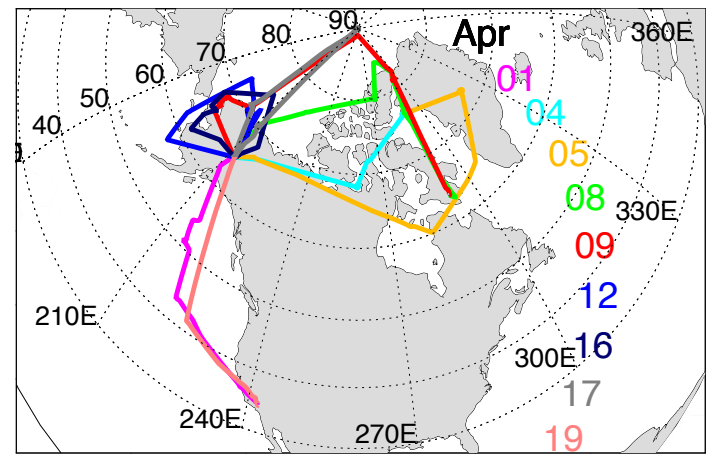

C

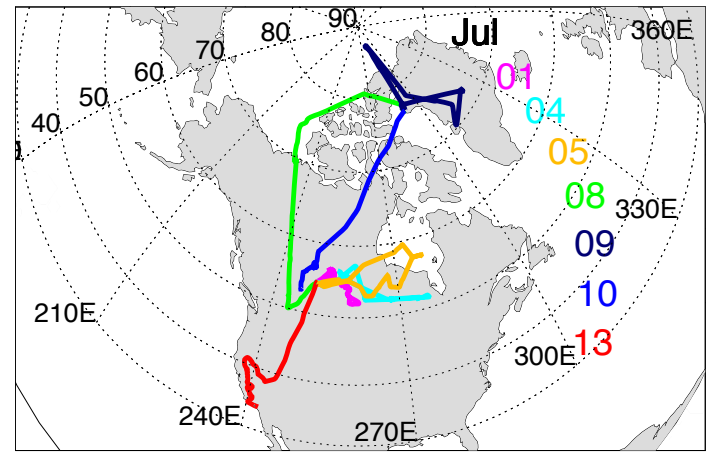

Fig. 1. (a) Regions for tagged CO emissions. In this work we use 3 tagged fossil fuel $\mathrm{CO}$ tracers and 2 tagged biomass burning tracers: F1. North American fossil fuel (NAFF, yellow), F2. Southern Asian fossil fuel (ASFF, red), F3. Europe fossil fuel (EUFF, green), B1. Non-boreal biomass burning (NBBB, light-blue shaded area), and B2. Boreal biomass burning (BOBB, non-light-blue area). (b) and (c) NASA DC-8 flight tracks during ARCTAS-A (April, based at Fairbank, USA) and ARCTAS-B (July, based at Cold Lake, Canada), respectively.

with the optimized GEOS-Chem CO emissions in April (see GEOS-Chem emissions in Table 2).

$\mathrm{BC}$ is also emitted from anthropogenic and biomass burning sources. In April the biomass burning emission is 30$40 \%$ higher than anthropogenic emission, but in July these two sources are roughly comparable. The most important sources of $\mathrm{BC}$ are similar to those of $\mathrm{CO}$, i.e., ASFF and BOBB, in both April and July.

Uncertainty in the emissions of $\mathrm{CO}$ and $\mathrm{BC}$ is quite large, particularly in specific regions. Shindell et al. (2008) investigated pollution transported to the Arctic using 17 global models. The difference of the emissions of $\mathrm{CO}$ and $\mathrm{BC}$ among the models are as great as a factor of two between the minimum and maximum over the four polluted regions of East Asia, South Asia, North America, and Europe in their baseline simulation. In comparison, emissions of $\mathrm{CO}$ and $\mathrm{BC}$ over East and South Asia in GEOS-5 are close to the maximum value, while the emissions over North America and Europe are close to or even slightly below the minimum value of the multi-model range in Shindell et al. (2008). Considering that their baseline simulation was for the year 2001 and the emission trends differ over the regions (i.e., increase $\sim 20 \%$ of anthropogenic emission over Asia and decrease $\sim 40 \%$ over North America and Europe from 2001 to 2008), GEOS5 emissions should be consistent with the other models.

\section{Model evaluation and analysis of ARCTAS data}

\section{1 $\mathrm{CO}$ and $\mathrm{BC}$ concentrations}

Vertical distributions of $\mathrm{CO}$ volume mixing ratios from DC-8 measurements and GEOS-5 simulation are shown in Fig. 2a and $b$ for ARCTAS-A and -B in April and July 2008, respectively. The model output was sampled at the time, latitude, longitude, and altitude of the 1 min merged DC- 8 measurements, with both the model and data values further averaged in $1 \mathrm{~km}$ vertical bins. The mean and standard deviation of the data are shown as red bars in Fig. 2. The modeled CO from other than the aforementioned five tagged categories is designated as "Other CO". This "Other CO" comes mainly from the $\mathrm{CO}$ produced by $\mathrm{CH}_{4}$ oxidation, which typically accounts for about $30 \%$ of global CO source (e.g., Arellano et al., 2006; Bian et al., 2007; Duncan et al., 2007).

The April campaign (ARCTAS-A) was conducted in Alaska, focusing on the long-range transport of midlatitude pollutants. This long-range transport can be seen by a large fraction of CO from ASFF in Fig. 2a. Together, the midlatitude anthropogenic emissions from Asia, Europe, and North America account for nearly $50 \%$ of $\mathrm{CO}$ along the DC-8 flight track in April, with the ASFF contributing most (about $25 \%)$.

The July campaign (ARCTAS-B) was based at Cold Lake, Canada. The areas covered by the July campaign experienced strong influence from local fires so that model calculated $\mathrm{CO}$ from BOBB is extremely high ( $>60 \%$ of total five CO tags) from the surface up to $3 \mathrm{~km}$ (Fig. 2b). CO transported from Asia peaks at high altitudes $(\sim 9 \mathrm{~km})$ contributing to about half of the $\mathrm{CO}$ there. In both campaigns the background $\mathrm{CO}$, mostly produced from $\mathrm{CH}_{4}$ oxidation, is high (about $1 / 3$ of total CO as shown by the "Other CO"). The general 
a

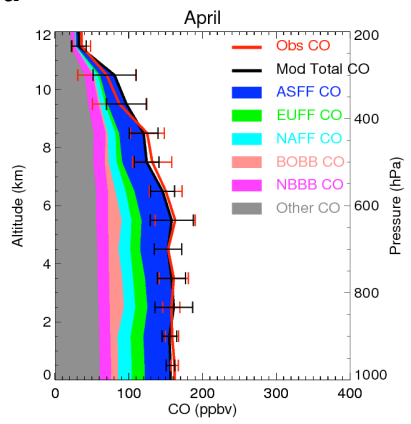

b

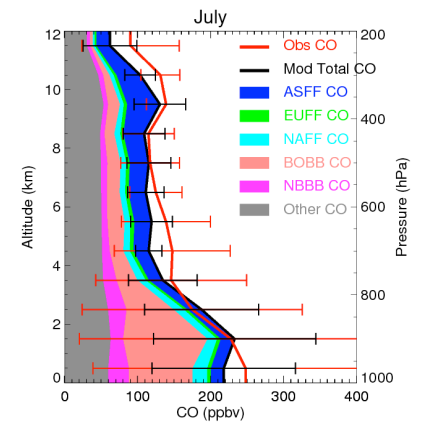

Fig. 2. Vertical distribution of the $\mathrm{CO}$ volume mixing ratio (ppbv) from DC-8 measurements and the GEOS-5 simulation when the GEOS-5 model results are sampled by all flights for April (a) and July (b). The DC-8 CO from along the flight tracks is shown by the solid thick red line with standard deviation shown by horizontal bars. GEOS-5 CO is shown by the thick black line for total and by the color-shaded areas for the corresponding tagged components. The "Other CO" refers to the global CO other than the five tagged COs defined in Fig. 1a and it is mostly attributed to the CO chemical formation from methane oxidation.
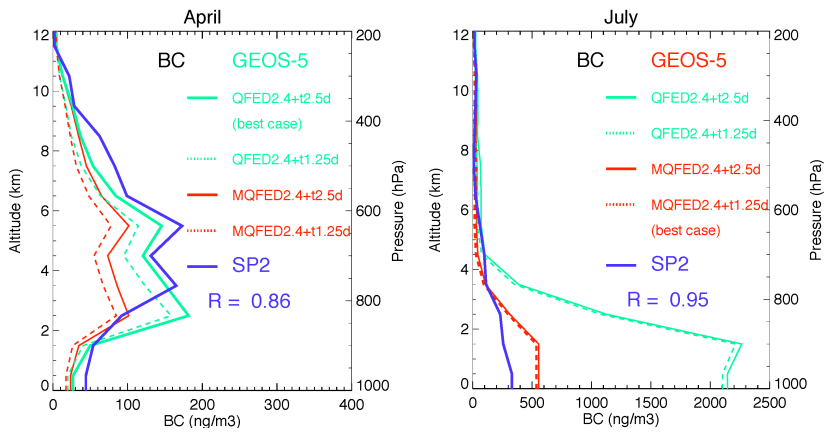

Fig. 3. Vertical distribution of $\mathrm{BC}$ mass concentration $\left(\mathrm{ng} \mathrm{m}^{-3}\right)$ from DC-8 measurement and GEOS-5 simulations when the GEOS5 model results are sampled by all flights for April (Fig. 2a) and July (Fig. 2b). Four model sensitivity experiments were conducted to test the different biomass burning emissions (green line for QFED 2.4 and red line for Modified QFED 2.4) and BC aging e-folding timescales (solid line for e-folding time 2.5 days and dash line for 1.25 days). The thick lines (i.e., green solid line in April and red dashed line in July) are the "best" simulations used in the discussion of source attribution. Correlations between the measurement and the best model simulation are given.

consistency between model and observations on $\mathrm{CO}$ concentrations and vertical profiles suggests that the GEOS-5 is capable of reproducing the average levels of observed $\mathrm{CO}$.

The model-measurement comparison for BC is shown in Fig. 3 with similar data binning as in Fig. 2. Four model sensitivity simulations are shown in the figure to test the range of contributions from biomass burning emissions and $\mathrm{BC}$ aging times (conversion time from hydrophobic to hydrophilic). The green lines represent $\mathrm{BC}$ biomass burning

emission from QFED v2.4, while red lines stand for modified QFED v2.4 BC emissions where the enhancement factor over extra-tropical areas was set to 1 . The different line styles are associated with $\mathrm{BC}$ e-folding aging times, with solid lines for 2.5 days and dashed lines for 1.25 days.

The changes of $\mathrm{BC}$ biomass burning emission and efolding aging times both have significant impact on modeled $\mathrm{BC}$ vertical profiles in April. The best agreement comes from the simulation driven by standard QFED v2.4 emission with an e-folding aging time of 2.5 days (green solid line). On the other hand, in July the BC concentrations at lower altitudes (e.g., below $4 \mathrm{~km}$ ) are predominantly controlled by the local biomass burning emissions as the DC- 8 often flew through the biomass burning plumes. Figure $3 \mathrm{~b}$ clearly suggests that the biomass burning emission from the standard QFED is too high (by a factor of 7). By removing the "enhancement factor" from the standard QFED, the agreement between model and observation is much improved, even though the model is still $50-70 \%$ higher than the observations below $4 \mathrm{~km}$. Although the change of $\mathrm{BC}$ aging time makes little difference on the average $\mathrm{BC}$ vertical profile in Fig. 3b, using a faster e-folding time allows the model to better represent the "background" BC (i.e., $\mathrm{BC}$ concentrations below $10 \mathrm{ng} \mathrm{m}^{-3}$ ) when compared to measurements from each individual flight (see Fig. S4 in the Supplement). Therefore, using the ARCTAS data as guidance, we select the optimal parameters within the range of BC e-folding time (Sect. 2.2) and biomass burning emission (Sects. 2.3 and 3.1) in model simulation: the adjusted (reduced) biomass burning emission in July, and a season-dependent BC aging time (slower in April than July) that possibly reflect the influences of humidity and temperature on the $\mathrm{BC}$ aging process.

More evaluations of model simulation are presented in the Supplement. CO and BC concentrations from model and observation along each flight track during April and July are shown in Figs. S1-S4. A composite of the DC-8-measured $\mathrm{CO}$ mixing ratios compared to the total $\mathrm{CO}$ mixing ratio simulated by the GEOS-5 model along the flight tracks is presented in Fig. S5, along with a similar comparison for BC in Fig. S6.

\subsection{Air mass origin}

GEOS-5 uses 5 tagged CO tracers (Fig. 1a) to track contributions of different sources to the Western Arctic. To evaluate the reliability of this model, we analyze the correlation of the modeled anthropogenic $\mathrm{CO}$ (i.e., FF, the total of ASFF, NAFF, and EUFF) with observed dichloromethane $\left(\mathrm{CH}_{2} \mathrm{Cl}_{2}\right)$ (Fig. 4a and b), a well-known fossil fuel tracer (Moore et al., 2004), and the correlation of the modeled biomass burning $\mathrm{CO}$ (i.e., $\mathrm{BB}$, the total of $\mathrm{BOBB}$ and $\mathrm{NBBB}$ ) with observed acetonitrile $\left(\mathrm{CH}_{3} \mathrm{CN}\right)$ (Fig. $4 \mathrm{c}$ and d), a well-known biomass burning tracer (Gouw et al., 2003; Li et al., 2003; Singh et al., 2003). Both tracers have a lifetime on the order of 5 months. 

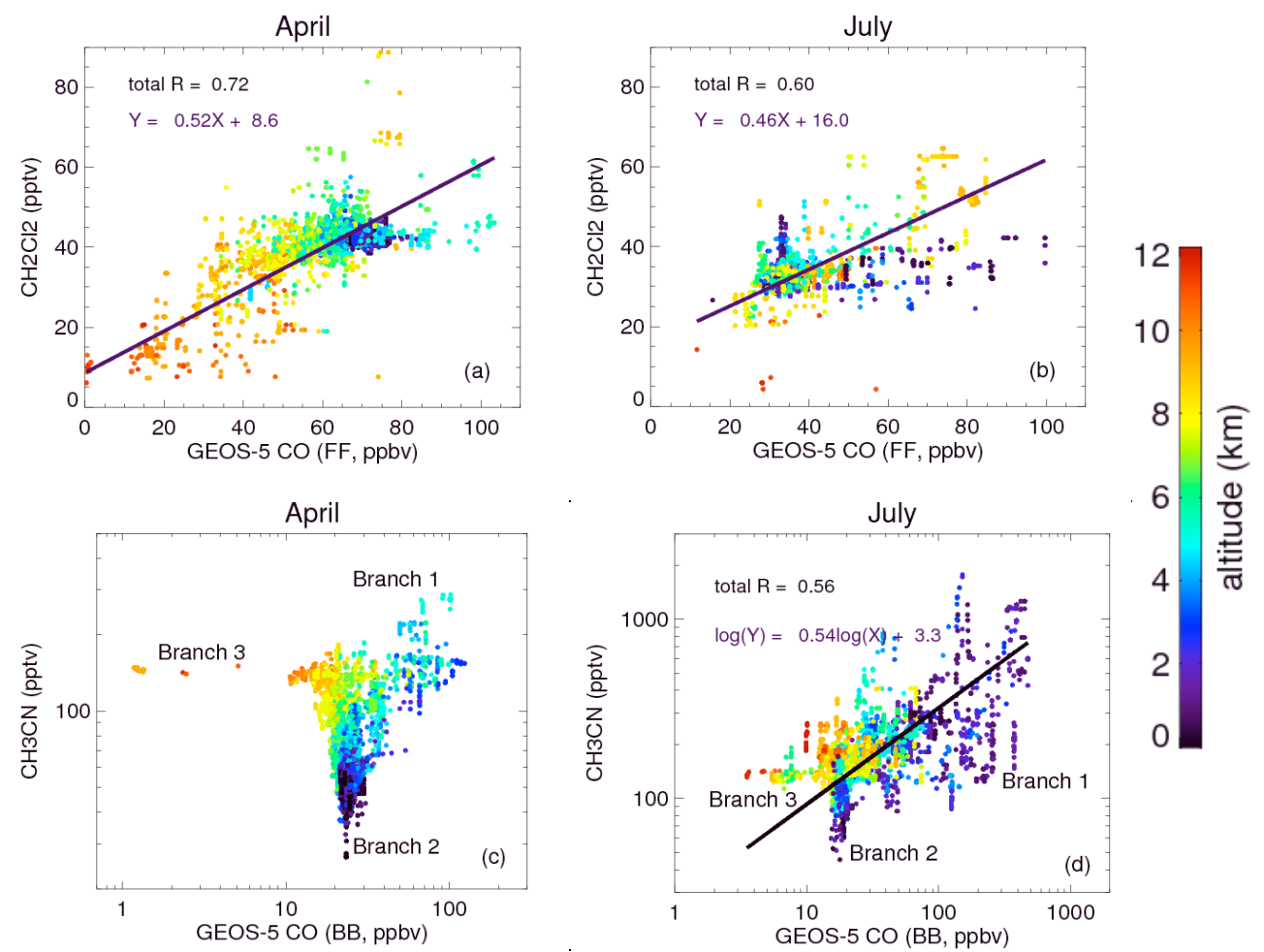

Fig. 4. Top: scatter plots of observed $\mathrm{CH}_{2} \mathrm{Cl}_{2}$ (pptv) and modeled fossil fuel tagged $\mathrm{CO}$ (ppbv) from Asia, North America, and Europe in April (a) and July (b). Bottom: scatter plots of observed $\mathrm{CH}_{3} \mathrm{CN}$ (pptv) and modeled biomass burning tagged $\mathrm{CO}$ (ppbv) from boreal and non-boreal regions in April (c) and July (d). The results are colored according to the measurement altitudes. Each point represents median values of model results and observations within $10 \mathrm{~min}$.

The modeled FF CO is correlated with observed $\mathrm{CH}_{2} \mathrm{Cl}_{2}$ in both campaigns (i.e., both $R \geq 0.6$ ), as shown in Fig. 4a and $4 \mathrm{~b}$. This is direct evidence that the model can capture the air mass that is transported from the midlatitudes well. The linear fitting analysis indicates that the ratio of tagged FF CO and observed $\mathrm{CH}_{2} \mathrm{Cl}_{2}$ is higher in July than in April. The CO chemistry does not support this since more $\mathrm{CO}$ is lost to its reaction with $\mathrm{OH}$ in July. To answer this a detailed analysis of the emission ratio between $\mathrm{CO}$ and $\mathrm{CH}_{2} \mathrm{Cl}_{2}$ in every anthropogenic emission sectors is needed, but the study is beyond the scope of this paper.

In contrast to the correlation between tagged $\mathrm{FF}$ and observed $\mathrm{CH}_{2} \mathrm{Cl}_{2}$, the correlation between the tagged $\mathrm{BB} \mathrm{CO}$ and the observed $\mathrm{CH}_{3} \mathrm{CN}$ is much more complicated (Fig. $4 \mathrm{c}$ and d). Even though $\mathrm{CH}_{3} \mathrm{CN}$ is a widely used biomass burning tracer, our analysis indicates that the $\mathrm{CH}_{3} \mathrm{CN}$ and $\mathrm{BB} \mathrm{CO}$ do not always covary. There are clearly three branches in the $\mathrm{CO}-\mathrm{CH}_{3} \mathrm{CN}$ relationship. Branch 1 shows covarying $\mathrm{CO}$ and $\mathrm{CH}_{3} \mathrm{CN}$ concentrations that predominantly result from their common biomass burning sources. Branch 2 shows an elevated $\mathrm{CO}$ but low $\mathrm{CH}_{3} \mathrm{CN}$ when sampling from Arctic marine boundary layer (AMBL) air since $\mathrm{CH}_{3} \mathrm{CN}$ is taken up by the ocean. Branch 3 shows an elevated $\mathrm{CH}_{3} \mathrm{CN}$ but low $\mathrm{CO}$ in stratospheric air since $\mathrm{CH}_{3} \mathrm{CN}$ has a longer lifetime than $\mathrm{CO}$. These behaviors are nicely confirmed by the alti- tude color coding. Branch 1 clearly controls the $\mathrm{CO}-\mathrm{CH}_{3} \mathrm{CN}$ relationships in July as the DC-8 frequently sampled biomass burning air masses during ARCTAS-B. This 3-branch behavior is shown better in the scatter plot of total $\mathrm{CO}$ and observed $\mathrm{CH}_{3} \mathrm{CN}$, in Fig. 5, where the total $\mathrm{CO}$ shown originates from both the observations and the model results. The characteristics of these different $\mathrm{CO}-\mathrm{CH}_{3} \mathrm{CN}$ relationships are captured by the model (Fig. 5b and d).

To demonstrate the utility of air mass identification using the tagged tracers or observed $\mathrm{CH}_{2} \mathrm{Cl}_{2}$ and $\mathrm{CH}_{3} \mathrm{CN}$ as tracers, we show in Fig. 6 the flight on 8 July from Cold Lake, Canada, to Thule, Greenland (ARCTAS-B, flight 21), as a detailed case study. This flight encountered two high CO plumes: one over the US-Canada border (waypoints 1-3) and the other over the Arctic near Greenland (waypoints 810) (see Fig. 1c for the flight route, the waypoints are evenly distributed along flight track). The simulated tagged $\mathrm{CO}$ concentrations along the flight tracks are shown in Fig. 6a and the observed $\mathrm{CH}_{2} \mathrm{Cl}_{2}$ and $\mathrm{CH}_{3} \mathrm{CN}$ in Fig. $6 \mathrm{~b}$. To better understand the contributions from different source regions, curtain plots of the tagged $\mathrm{CO}$ along the flight track are shown in Fig. 6c-d, respectively, for its major sources BOBB and ASFF.

Analysis of the atmospheric circulation revealed that the jet stream consisted of two segments over Asia. The southern 

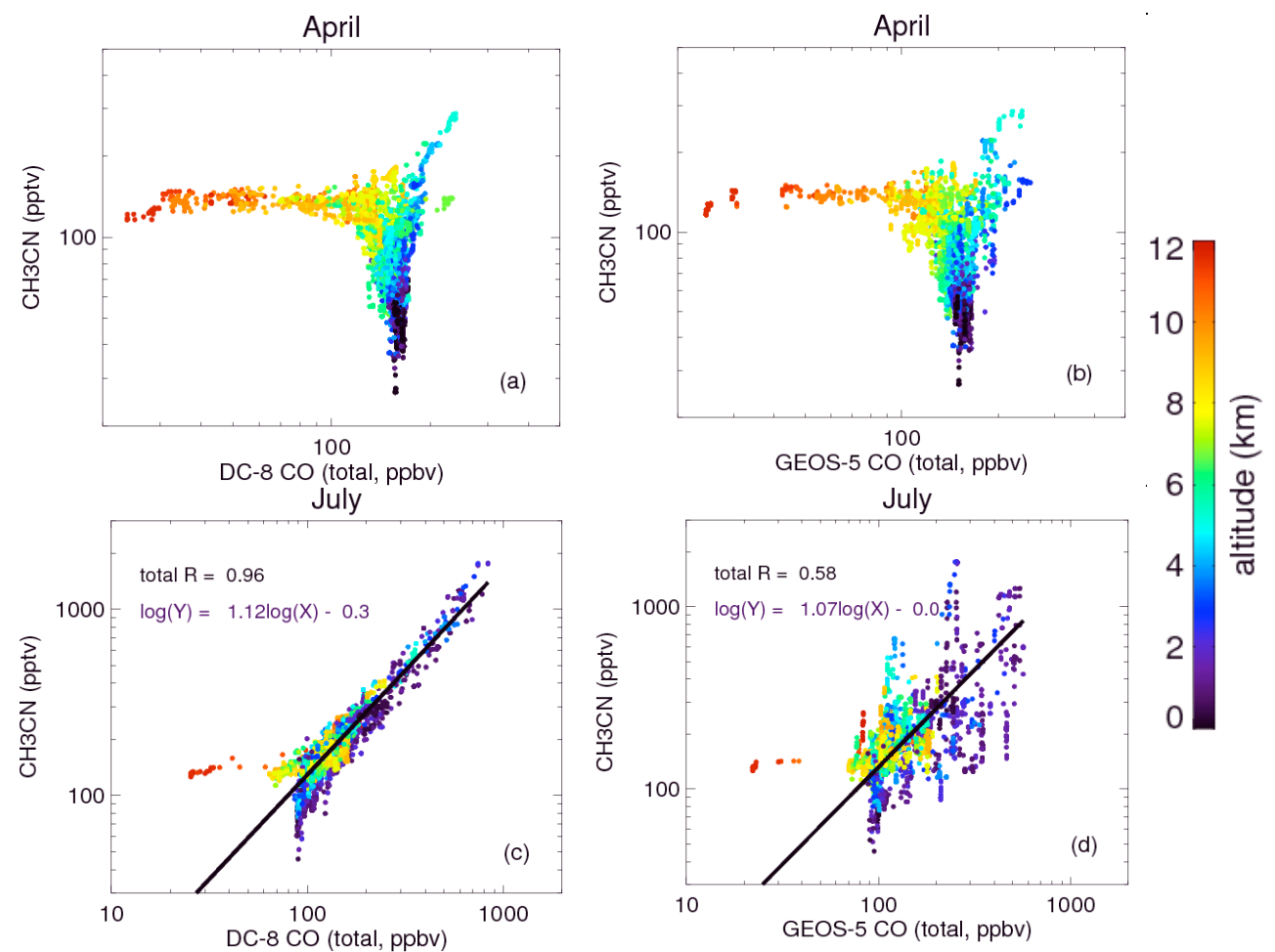

Fig. 5. Scatter plots of observed $\mathrm{CH}_{3} \mathrm{CN}$ (pptv) and DC-8 observed $\mathrm{CO}$ (ppbv) (a and c) and of observed $\mathrm{CH}_{3} \mathrm{CN}$ (pptv) and GEOS-5 simulated total CO (b and d) in ARCTAS-A and -B campaigns. The results are colored according to the measurement altitudes. Each point represents median values of model results and observations within $10 \mathrm{~min}$.

segment passed over Central Asia and was near the climatological position, while the segment over extreme northern Asia was $\sim 10 \mathrm{~m} \mathrm{~s}^{-1}$ stronger than its weaker climatological counterpart (Fig. 16 in Fuelberg et al., 2010). Ten day back trajectories from the aircraft tracks show that both the southern and northern plumes came from Asia and its surrounding areas. More specifically, the southern plume originated from Asia and Eurasia and the northern plume from Northeast Asia and the Labrador Sea (Fuelberg et al., 2010, http://fuelberg.met.fsu.edu/research/arctas/traj/traj/html).

The tagged $\mathrm{CO}$ simulations, indicated by the colored lines in Fig. 6a, show that the sampled CO concentration in the southern plume had comparable Asian industrial and boreal biomass burning pollution contributions, while the sampled $\mathrm{CO}$ in the northern plume was mainly due to Asian industrial pollution, consistent with the origin of the plumes analyzed by Fuelberg et al. (2010). The contribution and distribution of BOBB and ASFF can be identified more easily from Fig. 6cd. Although both emission sources contributed to the two plumes, their peaks are slightly displaced vertically. In particular, for the northern $\mathrm{CO}$ plume, the Asian anthropogenic influence peaks at $300-400 \mathrm{hPa}$, higher than the $400-500 \mathrm{hPa}$ peak of the calibrating initially against plume, so the flight captured mostly ASFF at its flight altitude. This layering of plumes, i.e., the ASFF plume just above the BOBB plume, was also observed by previous studies (Matsui et al., 2011a; Singh et al., 2010).

In general, the observed $\mathrm{CH}_{2} \mathrm{Cl}_{2}$ and $\mathrm{CH}_{3} \mathrm{CN}$ have similar variations along the flight track as the model ASFF and BOBB, respectively. This comparison further indicates that the tagged $\mathrm{CO}$ tracers adequately represent the origin of air masses.

\subsection{Age and origin of air masses diagnosed by the $\mathrm{BC} / \mathrm{CO}$ ratio}

As noted earlier, $\mathrm{CO}$ and aerosol $\mathrm{BC}$ have common sources from anthropogenic and biomass burning but different removal and chemistry processes. Given these similarities and differences, it is possible to use correlations of $\mathrm{BC}$ and $\mathrm{CO}$ to estimate air mass ages and origins.

The ratios of $\mathrm{BC}$ to $\mathrm{CO}$ from DC- 8 measurements and the GEOS-5 model in the two ARCTAS campaign periods are shown in Fig. 7. The older the air is, the smaller the BC/CO ratio will be, simply because the lifetime of $\mathrm{BC}$ is much shorter than $\mathrm{CO}$ since $\mathrm{BC}$ is removed much faster through dry and wet scavenging than $\mathrm{CO}$. The ratios in the figure are calculated from $\mathrm{BC}$ and total $\mathrm{CO}$, but are sorted according to the dominant sources of tagged $\mathrm{CO}$. Here the dominant $\mathrm{CO}$ refers to the CO tag having the greatest value, as well as its value being not less than $40 \%$ of the total $\mathrm{CO}$. We show only 

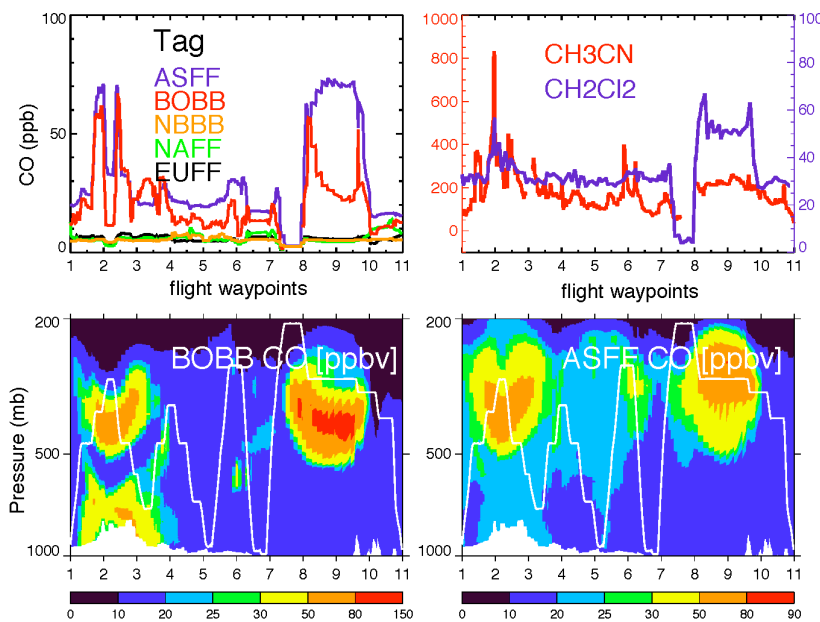

Fig. 6. Top left: the five tagged $\mathrm{CO}$ mixing ratios during the ARCTAS flight 21 on 8 July from Cold Lake, Canada, terminating in Thule, Greenland. Top right: the corresponding measured $\mathrm{CH}_{3} \mathrm{CN}$ and $\mathrm{CH}_{2} \mathrm{Cl}_{2}$ during the same flight. Bottom left and bottom right are curtain plots for the tagged $\mathrm{CO}$ species BOBB and ASFF, respectively, with the white line representing the flight track.
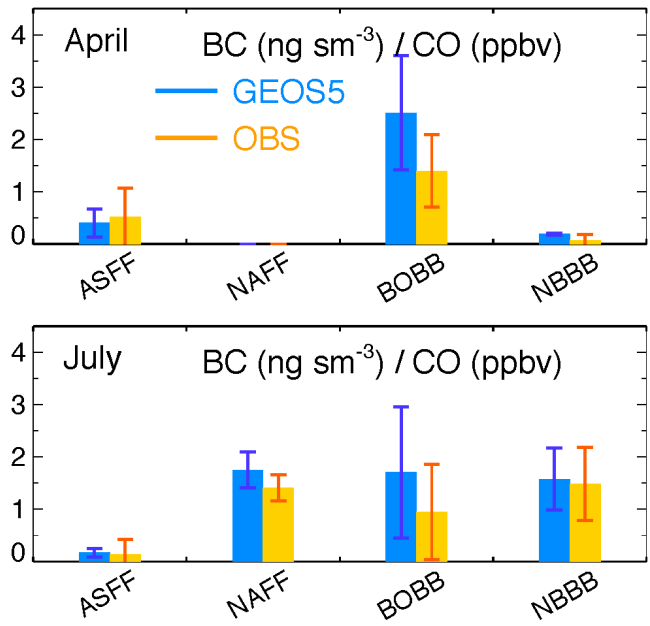

Fig. 7. The statistical ratios between the mixing ratios of $B C$ [ng sm ${ }^{-3}$ ] to CO [ppbv] over ARCTAS-A (top) and ARCTAS-B (bottom) campaigns. The blue box represents model ratio and yellow box represents observed ratio. The ratios are sorted based on the dominant model $\mathrm{CO}$ tag in the measured pollution.

for those dominant $\mathrm{CO}$ tracers when there are more than ten 1 min sample numbers having both $\mathrm{BC}$ and $\mathrm{CO}$ values, so there is no ratio calculated for cases of EUFF in both campaigns and NAFF in April.

In ARCTAS-A the $\mathrm{BC} / \mathrm{CO}$ ratio is the smallest for $\mathrm{NBBB}$ $\left(\sim 0.15 \mathrm{BC}\left(\mathrm{ng} \mathrm{sm}^{-3}\right) / \mathrm{CO}(\mathrm{ppbv})\right)$, indicating that air coming from NBBB was the oldest (unit conversion from volume mixing ratio to mass concentration using standard temperature and pressure condition). During April the major NBBB emissions were from the low-latitudinal areas of Southeast
Table 3. The ratio of $\mathrm{BC} / \mathrm{CO}\left(\mathrm{Gg} \mathrm{Tg}^{-1}\right)$ from emissions in different source regions and from Arctic air samples in July.

\begin{tabular}{lllll}
\hline $\mathrm{BC}(\mathrm{Gg}) / \mathrm{CO}(\mathrm{Tg})$ & ASFF & NAFF & BOBB & NBBB \\
\hline Emission & 14 & 4 & 8 & 13 \\
Air sample (model) & 0.2 & 2 & 2 & 2 \\
Air sample (measurement) & 0.1 & 2 & 1 & 2 \\
\hline
\end{tabular}

Asia and other tropical regions such that $\mathrm{CO}$ and $\mathrm{BC}$ from NBBB had traveled a long distance to reach Alaska. In ARCTAS-B, the $\mathrm{BC} / \mathrm{CO}$ ratio is the lowest in the ASFF air mass $\left(\sim 0.15 \mathrm{BC}\left(\mathrm{ng} \mathrm{sm}^{-3}\right) / \mathrm{CO}(\mathrm{ppbv})\right)$, but similar in NBBB and NAFF samples $\left(\sim 1.7 \mathrm{BC}\left(\mathrm{ng} \mathrm{sm}^{-3}\right) / \mathrm{CO}(\mathrm{ppbv})\right)$, reflecting the longer traveling distance of Asian air mass to Canada than the North American air mass that contains pollutants from NAFF and NBBB (Californian fire). Although the mean $\mathrm{BC} / \mathrm{CO}$ ratio of NOBB from GEOS-5 is higher than that from the observation, model and measurement data are consistently showing that the $\mathrm{BC} / \mathrm{CO}$ ratio has the largest variation in BOBB (indicated by the highest standard deviation) because of the two distinct origins: one was from local Canadian boreal fire (fresh) and the other was transported from Eurasia region (aged). The $\mathrm{BC} / \mathrm{CO}$ ratio in ASFF was larger in April than in July, which is at least partially due to more $\mathrm{BC}$ wet scavenging occurring during the Asia-Arctic transport in July (Matsui, et al., 2011a).

We also do a first-order check for the ratio of $\mathrm{BC} / \mathrm{CO}$ in ARCTAS-B by comparing their values with the ratios of $\mathrm{BC} / \mathrm{CO}$ from emissions data. Theoretically, the former should be smaller than the latter since $\mathrm{BC}$ is lost faster than $\mathrm{CO}$ during transport. In July the emission ratios of $\mathrm{BC} / \mathrm{CO}$ (Table 3) are in the $4-14\left(\mathrm{Gg} \mathrm{Tg}^{-1}\right)$ range for the five tagged $\mathrm{CO}$ tracers, which are larger than the $\mathrm{BC} / \mathrm{CO}$ ratio in the air samples that are within $0.2-2\left(\mathrm{Gg} \mathrm{Tg}^{-1}\right)$ in the tagged $\mathrm{CO}$ approach and $0.1-2\left(\mathrm{Gg} \mathrm{Tg}^{-1}\right)$ from observations. The BC/CO ratio of the tagged ASFF air mass has the largest change from its emission to the target air sample. This is understandable, given that the emission from the ASFF is more remote and the large precipitation was reported along trajectories from Asian anthropogenic air to the Cold Lake, Canada, in July (Matsui, et al., 2011a).

\section{Regional source attribution of $\mathrm{CO}$ for the Western Arctic}

Since CO and aerosols are not uniformly distributed and the aircraft measurements can only cover a small area in a limited time frame, the question often arises: how representative are the findings from the ARCTAS field experiments for the larger Arctic region? Here we use the GEOS-5 model to estimate the pollution sources in the Western Arctic domain to put the ARCTAS results into a regional context. 
a

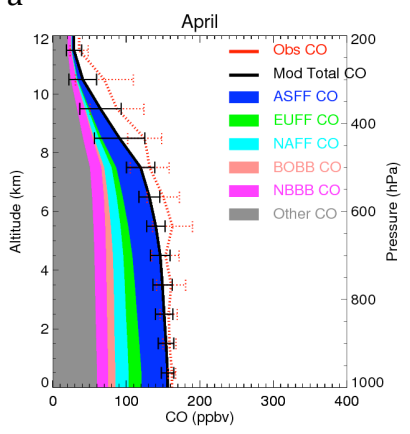

b

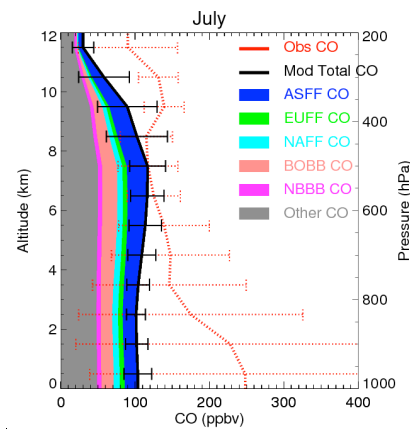

Fig. 8. Vertical distribution of the CO volume mixing ratio (ppbv) from GEOS-5 simulation when the model results are averaged over the Arctic region 50N-90N and 190E-320E for April (a) and July (b). The GEOS-5 CO is shown by the thick black line for total and by the color shaded areas for the corresponding tagged components. The "Other CO" refers to the global CO other than the five tagged $\mathrm{CO}$ species defined in Fig. 1a and it is mostly attributed to the $\mathrm{CO}$ chemical formation from methane oxidation. The $\mathrm{CO}$ mixing ratio from along the DC- 8 flight tracks is also shown by the dotted red line with the standard deviation shown by horizontal bars for a reference.

The vertical profiles of the $\mathrm{CO}$ volume mixing ratio averaged over the entire Western Arctic domain (between 50$90^{\circ} \mathrm{N}$ and $170-40^{\circ} \mathrm{W}$ ) from GEOS-5 are shown in Fig. 8a (April 2008) and Fig. 8b (July 2008). The CO results from DC-8 measurements are plotted in dotted lines. The similarity between Figs. 2a and 8a in terms of $\mathrm{CO}$ concentrations and source attribution implies that the pollutants in April 2008 were relatively well mixed and homogenously distributed in the Western Arctic and the ARCTAS-A data provide an adequate representation of the region, even though the flight planning during the mission often directed aircraft to capture the transported pollution plumes. In contrast, in July the fire plumes from BOBB in Canada were specifically targeted during ARCTAS-B, which were highly inhomogeneous in both space and time. The large difference between Fig. 2b (flight track average) and Fig. 8b (regional average) in total CO and source apportionment from GEOS-5 clearly indicates that it would be inappropriate to consider the ARCTAS-B data as representative to the average atmospheric state of Western Arctic in July 2008.

The regional mean tagged $\mathrm{CO}$ vertical distributions shown in Fig. 8a for April 2008 indicate that the Western Arctic air was largely impacted by ASFF from the surface to the upper troposphere in addition to background $\mathrm{CO}$ level represented by the "Other CO". This Asian contribution exceeds the combined contributions from NAFF and EUFF, particularly in free troposphere. The contribution from biomass burning sources $(\mathrm{BOBB}+\mathrm{NBBB})$ is about $2 / 3$ of the Asian fossil fuel contribution in April. Our results support the findings that Asian anthropogenic emissions are the most important source to the enhanced Arctic $\mathrm{CO}$ in the troposphere in

April (Fisher et al. 2010; Warneke et al., 2010). Nevertheless, the background $\mathrm{CO}$, which accounts for about $1 / 3$ of the Western Arctic $\mathrm{CO}$ with the majority coming from the $\mathrm{CH}_{4}$ oxidation, is still the dominant source to the mean $\mathrm{CO}$ level in the Arctic. The standard deviation (with respect to spatial variation) is very small (within 15 ppbv or $10 \%$ of total $\mathrm{CO}$ ) in the lower Arctic atmosphere, indicating a relatively homogeneous $\mathrm{CO}$ distribution. The European pollution, which had been a major source of Arctic pollution in the earlier decades (Quinn et al., 2007, 2008; Shaw 1995), contributes less than $10 \%$ to CO concentrations in April 2008, and is mostly confined to the lower and middle troposphere. Contribution of NAFF is about half of ASFF throughout the troposphere.

In July 2008 (Fig. 8b), ASFF and BOBB were the most important sources for Arctic pollution (about $35 \%$ and $25 \%$ of non-background CO). EUFF contribution was very low (less than 5\%). Previous studies indicate that European pollution is largely enhanced during the high phase of the North Atlantic Oscillation $\left(\mathrm{NAO}^{+}\right)$compared to its low phases $\left(\mathrm{NAO}^{-}\right)$(Eckhardt et al., 2003). The NAO index was -1.07, $-1.73,-1.39$, and -1.27 in April, May, June, and July, 2008, respectively (http://www.cpc.ncep.noaa.gov/products/ precip/CWlink/pna/nao.timeseries.gif), suggesting a weaker than normal northward transport from Europe to the Arctic.

The contribution of ASFF to the Arctic mean CO is much less in summer than in April, which is due to a lower CO concentration and a weaker poleward advection in summer than in spring. There is a CO enhancement in the middle to upper troposphere around 6-9 km, which suggests that pollution is transported to the Arctic at high altitudes after being lifted over the source regions in the midlatitudes by strong convection in July.

We sort the GEOS-5 total CO according to the dominant $\mathrm{CO}$ tag for each grid box within the Western Arctic domain, as explained in Sect. 3.3. The probability distribution function (PDF) of modeled total CO was calculated for each of the five source groups, four of which are shown in Fig. 9. The EUFF tag was excluded from the figure since the sampled total $\mathrm{CO}$ was almost never dominated by the tagged $\mathrm{Eu}-$ ropean pollution. The PDFs from the observation and model along flight tracks are also shown in the figure as an additional model evaluation.

Figure 9 implies qualitatively how polluted Arctic air would be due to each outstanding source and type. During ARCTAS-A the Arctic air would be very clean if the majority of pollution came from NBBB (i.e., the probable total CO mixing ratio is very low). In this case the air from the nonboreal region must travel long distances before arriving in the Arctic. During ARCTAS-B the CO PDFs show a longer tail toward higher $\mathrm{CO}$ compared to the spring distributions. This tail results mostly from the biomass burning sources (BOBB and NBBB) with high-intensity episodes (CO > 350 ppbv), or from a relatively local anthropogenic source (NAFF) with frequently high Arctic $\mathrm{CO}(\mathrm{CO} \sim 200 \mathrm{ppbv})$. In addition, the most probable $\mathrm{CO}$ from $\mathrm{BOBB}$ during July was less than 

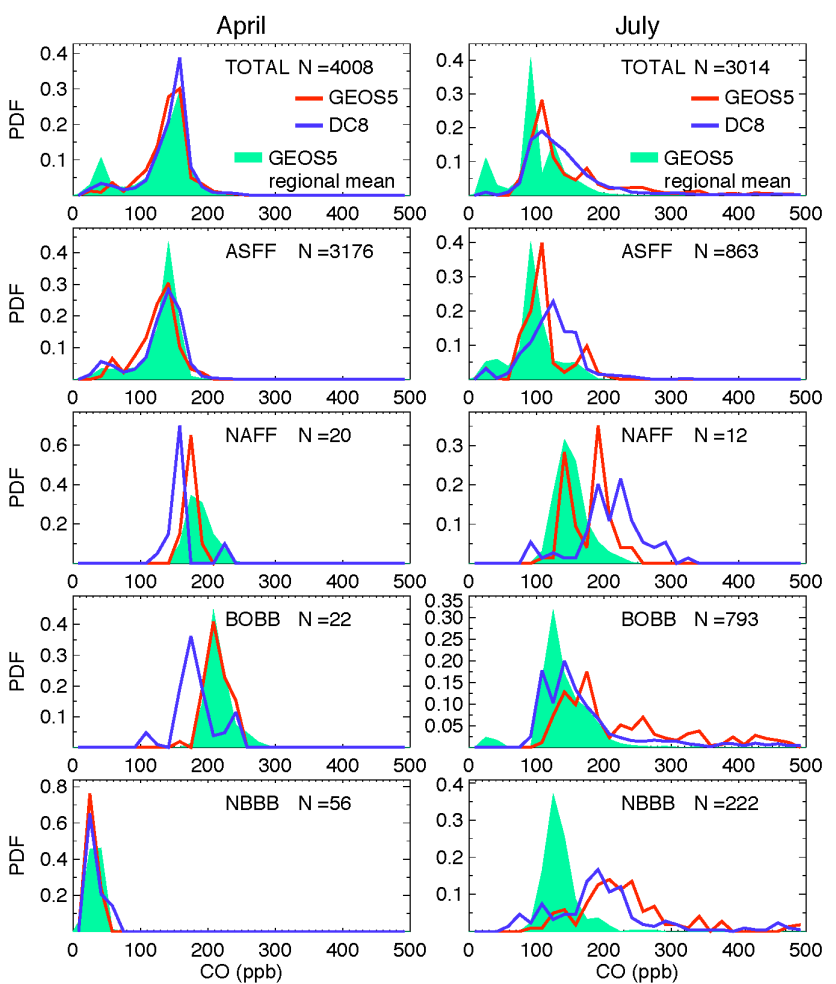

Fig. 9. The probability distribution function (PDF) of total $\mathrm{CO}$ over two ARCTAS campaign periods and over the 4 tagged CO categories. Please note EUFF is not shown since CO from European anthropogenic emissions seldom dominated the Arctic $\mathrm{CO}$ during the campaign. The green areas are the PDFs of GEOS-5 CO over the Arctic region $50 \mathrm{~N}-90 \mathrm{~N}$ and $190 \mathrm{E}-320 \mathrm{E}$ and up to $200 \mathrm{hPa}$. The blue and red lines are the PDFs of DC- 8 and GEOS-5 sampled along flight tracks and $N$ is number of 1 min data point.

during April although both local and Russian BB CO emissions during summer were larger than during spring. This indicates that a smaller fraction of Russian BB CO was transported to the Arctic in summer than in spring.

A campaign objective was to estimate the emissions from boreal forest fires and to investigate the near-field chemical evolution of the fire plume. MODIS data over Siberia from 2000-2009 indicated that fire counts during April 2008 were the highest recorded during that period, while the summer peak was second only to 2003 (Singh et al., 2010). Canadian fires during ARCTAS-B were near their normal level (Soja et al., 2008), while California experienced one of the largest episodes of wildfires in summer 2008, with over 1000 fires (Singh et al., 2010). Episodes from all these biomass burning emissions were detected during ARCTAS-B, as shown in Fig. 9. In April the Siberian fires were measured over Fairbanks, so BOBB gives the highest probable CO. During July, California fires (i.e., NBBB) are most prominent over Canada, as shown by the longer tail toward high CO. Local Canadian fires (i.e., BOBB) can cause extremely polluted episodes as shown by the small bumps at extremely high $\mathrm{CO}$.

\section{Conclusions}

We have analyzed $\mathrm{CO}$ and BC measured by the NASA DC- 8 aircraft during the 2008 ARCTAS spring and summer campaigns. These data were used to evaluate the GEOS-5 model simulations. We have also used the observed $\mathrm{CH}_{2} \mathrm{Cl}_{2}$, a fossil fuel tracer, and $\mathrm{CH}_{3} \mathrm{CN}$, a biomass burning tracer, to evaluate the capability of tagged $\mathrm{CO}$ tracers in characterizing air mass origins, and the ratio of $\mathrm{BC} / \mathrm{CO}$ to estimate the age of air. Finally, the model is used to attribute the pollutants regionally in the Western Arctic to their source origins.

The model results agree well with the aircraft measurements along the flight tracks, particularly representing long-distance transport of air pollution tracers (from Asian sources) in April. The model reveals that the ARCTAS DC-8 measurements are representative of the regional Arctic pollution in the spring (April, ARCTAS-A) due to relatively homogeneous tracer distribution. The aircraft data alone, however, are insufficient to provide a comprehensive and representative picture of Arctic pollution in the summer (July, ARCTAS-B) because the flights targeted local fire plumes. The tagged $\mathrm{CO}$ tracers are able to characterize the air mass source regions, as shown by the clear correlation between ASFF $\mathrm{CO}$ and $\mathrm{CH}_{2} \mathrm{Cl}_{2}$ and between BOBB $\mathrm{CO}$ and $\mathrm{CH}_{3} \mathrm{CN}$. The capability of tagged $\mathrm{CO}$ tracers in identifying pollution origins is further demonstrated in a case study from 8 July.

Our model results indicate that on average in both campaign periods the Western Arctic $\mathrm{CO}$ is dominated by background $\mathrm{CO}$ produced by $\mathrm{CH}_{4}$ oxidation. Asian anthropogenic pollution stands for the largest foreign source for the enhancement of the Western Arctic CO in April (accounting for $\sim 25 \%$ of the total Arctic CO), during which biomass burning contributes roughly $2 / 3$ as much as ASFF. In July both ASFF and BOBB have comparable contributions to the mean CO. Biomass burning also makes a large contribution to the Arctic pollution variability in July. On the other hand, we found that European sources seldom made important contributions to the $\mathrm{CO}$ in the campaign domain and period, perhaps because the NAO was negative.

Our results show that transported pollution from Asian emissions is the most important foreign fossil fuel and biomass burning sources of $\mathrm{CO}$ and $\mathrm{BC}$ to the Western Arctic throughout the troposphere during April, and in the middleupper troposphere $(6-10 \mathrm{~km})$ during July, with stronger transport capability during spring than summer.

The ratio of $\mathrm{BC} / \mathrm{CO}$ can be used as an indicator of air mass age and origin. The air masses originating from Asian anthropogenic emissions were relatively old, while those from boreal biomass burning emission were relatively young in both campaigns. The ratio varies most in the July BOBB case due to the two distinct origins from local Arctic boreal fires and from Eurasia. The ratio of ASFF is larger in April than in July, which is consistent with more BC wet scavenging occurring during the Asia-Arctic transport in July. 
During ARCTAS-B the local boreal biomass burning sources from the standard QFED seemed to significantly overestimate the emissions. The ARCTAS observations are used to constrain this emission. Even so, the modelmeasurement comparisons indicate that the model still has difficulties to capture the location and time of local boreal forest fire emissions. Despite this deficiency the model is useful in representing the Western Arctic region-wide pollution as the regional mean $\mathrm{CO}$ is less impacted by the local events. Furthermore, using a varying conversion time for BC from hydrophobic to hydrophilic (i.e., 2.5 days in ARCTAS-A and 1.25 days in ARCTAS-B) yields a better model-observation agreement of $\mathrm{BC}$ mass concentration.

\section{Supplementary material related to this article is available online at: http://www.atmos-chem-phys.net/13/ 4707/2013/acp-13-4707-2013-supplement.pdf.}

Acknowledgements. The authors thank Anne Douglass, Steven Pawson, Jack Dibb, Jose-Luis Jimenez, Hanwant B. Singh, and Erin P. Czech for their helpful discussion and the two reviewers who helped to improve the paper. $\mathrm{CH}_{3} \mathrm{CN}$ measurements were supported by the Austrian Federal Ministry for Transport, Innovation and Technology (BMVIT) within the Austrian Space Applications Programme. This work was supported by the NASA ARCTAS program, the NASA ACMAP program (NNX11AN72G), and the NASA MAP program (NNX10AK61G).

Edited by: A. Stohl

\section{References}

Arellano Jr., A. F. and Hess, P. G.: Sensitivity of top-down estimates of CO sources to GCTM transport, Geophys. Res. Lett., 33, L21807, doi:10.1029/2006GL027371, 2006.

Balkanski, Y. J., Jacob, D. J., Gardner, G. M., Graustein, W. C., and Turekian, K. K.: Transport and residence times of tropo- spheric aerosols inferred from a global three-dimensional simulation of 210Ph, J. Geophys. Res., 98, 20573-20586, 1993.

Barrie, L.: Arctic air pollution: An overview of current knowledge, Atmos. Environ., 20, 643-663, 1986.

Bian, H., Chin, M., Kawa, R., Duncan, B., Arellano Jr., A., and Kasibhatla, R.: Uncertainty of global CO simulations constraint by biomass burning emissions, J. Geophys. Res., 112, D23308, doi:10.1029/2006JD008376, 2007.

Bian, H., Chin, M., Kawa, S. R., Yu, H., Diehl, T., and Kucsera, T.: Multiscale carbon monoxide and aerosol correlations from satellite measurements and the GOCART model: Implication for emissions and atmospheric evolution, J. Geophys. Res., 115, D077302, doi:10.1029/2009JD012781, 2010.

Brock, C. A., Cozic, J., Bahreini, R., Froyd, K. D., Middlebrook, A. M., McComiskey, A., Brioude, J., Cooper, O. R., Stohl, A., Aikin, K. C., de Gouw, J. A., Fahey, D. W., Ferrare, R. A., Gao, R.-S., Gore, W., Holloway, J. S., Hübler, G., Jefferson, A., Lack, D. A., Lance, S., Moore, R. H., Murphy, D. M., Nenes,
A., Novelli, P. C., Nowak, J. B., Ogren, J. A., Peischl, J., Pierce, R. B., Pilewskie, P., Quinn, P. K., Ryerson, T. B., Schmidt, K. S., Schwarz, J. P., Sodemann, H., Spackman, J. R., Stark, H., Thomson, D. S., Thornberry, T., Veres, P., Watts, L. A., Warneke, C., and Wollny, A. G.: Characteristics, sources, and transport of aerosols measured in spring 2008 during the aerosol, radiation, and cloud processes affecting Arctic climate (ARCPAC) project, Atmos. Chem. Phys., 11, 2423-2453, doi:10.5194/acp-11-24232011, 2011.

Chin, M., P. Ginoux, S. Kinne, O. Torres, B. N. Holben, B. N. Duncan, R. V. Martin, J. A. Logan, A. Higurashi, and Nakajima, T.: Tropospheric aerosol optical thickness from the GOCART model and comparisons with satellite and sun photometer measurements, J. Atmos. Sci., 59, 461-483, 2002.

Colarco, P., da Silva, A., Chin, M., and Diehl, T.: On- line simulations of global aerosol distributions in the NASA GEOS-4 model and comparisons to satellite and groundbased aerosol optical depth, J. Geophys. Res., 115, D14207, doi:10.1029/2009JD012820, 2010.

Colman, J. J., Swanson, A. L., Meinardi, S., Sive, B. C., Blake, D. R., and Rowland, F. S.: Description of the Analysis of a Wide Range of Volatile Organic Compounds in Whole Air Samples Collected during PEM-Tropics A and B, Anal Chem., 1, 37233731, 2001.

Cooke, W. F., Liousse, C., Cachier, H., and Feichter, J.: Construction of a $1^{\circ} \times 1^{\circ}$ fossil fuel emission data set for carbonaceous aerosol and implementation and radiative impact in the ECHAM4 model, J. Geophys. Res., 104, 22137-22162, 1999.

Cubison, M. J., Ortega, A. M., Hayes, P. L., Farmer, D. K., Day, D., Lechner, M. J., Brune, W. H., Apel, E., Diskin, G. S., Fisher, J. A., Fuelberg, H. E., Hecobian, A., Knapp, D. J., Mikoviny, T., Riemer, D., Sachse, G. W., Sessions, W., Weber, R. J., Weinheimer, A. J., Wisthaler, A., and Jimenez, J. L.: Effects of aging on organic aerosol from open biomass burning smoke in aircraft and laboratory studies, Atmos. Chem. Phys., 11, 12049-12064, doi:10.5194/acp-11-12049-2011, 2011.

Darmenov, A. and da Silva, A.: The Quick Fire Emissions Dataset (QFED) - Documentation of versions 2.1, 2.2 and 2.4, NASA Technical Report Series on Global Modeling and Data Assimilation, NASA TM-2013-104606, Vol. 32., in preparation, 2013.

Diehl, T., Heil, A., Chin, M., Pan, X., Streets, D., Schultz, M., and Kinne, S.: Anthropogenic, biomass burning, and volcanic emissions of black carbon, organic carbon, and $\mathrm{SO}_{2}$ from 1980 to 2010 for hindcast model experiments, Atmos. Chem. Phys. Discuss., 12, 24895-24954, doi:10.5194/acpd-12-24895-2012, 2012.

Diskin, G. S., Podolske, J. R., Sachse, G. W., and Slate, T. A.: Open-Path Airborne Tunable 15 Diode Laser Hygrometer, in: Diode Lasers and Applications in Atmospheric Sensing, edited by: Fried, A., SPIE Proc., 4817, 196-204, 2002.

Duncan, B. N., Logan, J. A., Bey, I., Megretskaia, I. A., Yantosca, R. M., Novelli, P. C., Jones, N. B., and Rinsland, C. P.: The global budget of CO, 1988-1997: Source estimates and validation with a global model, J. Geophys. Res., 112, D22301, doi:10.1029/2007JD008459, 2007.

Eckhardt, S., Stohl, A., Beirle, S., Spichtinger, N., James, P., Forster, C., Junker, C., Wagner, T., Platt, U., and Jennings, S. G.: The North Atlantic Oscillation controls air pollution transport to the Arctic, Atmos. Chem. Phys., 3, 1769-1778, doi:10.5194/acp-3- 
1769-2003, 2003.

Fisher, J. A., Jacob, D. J., Purdy, M. T., Kopacz, M., Le Sager, P., Carouge, C., Holmes, C. D., Yantosca, R. M., Batchelor, R. L., Strong, K., Diskin, G. S., Fuelberg, H. E., Holloway, J. S., Hyer, E. J., McMillan, W. W., Warner, J., Streets, D. G., Zhang, Q., Wang, Y., and $\mathrm{Wu}, \mathrm{S}$.: Source attribution and interannual variability of Arctic pollution in spring constrained by aircraft (ARCTAS, ARCPAC) and satellite (AIRS) observations of carbon monoxide, Atmos. Chem. Phys., 10, 977-996, doi:10.5194/acp10-977-2010, 2010.

Fisher, J. A., Jacob, D. J., Wang, Q., Bahreini, R., Carouge, C. C., Cubison, M. J., Dibb, J. E., Diehl, T., Jimenez, J. L., Leibensperger, E. M., Meinders, M. B. J., Pye, H. O. T., Quinn, P. K., Sharma, S., van Donkelaar, A., and Yantosca, R. M.: Sources, distribution, and acidity of sulfate-ammonium aerosol in the Arctic in winter-spring, Atmos. Environ., 39, 7301-7318, doi:10.1016/j.atmosenv.2011.08.030, 2011.

Flanner, M. G., C. S. Zender, J. T. Randerson, and Rasch, P. J.: Present day cli- mate forcing and response from black carbon in snow, J. Geophys. Res., 112, D11202, doi:10.1029/2006JD008003, 2007.

Fuelberg, H. E., Harrigan, D. L., and Sessions, W.: A meteorological overview of the ARCTAS 2008 mission, Atmos. Chem. Phys., 10, 817-842, doi:10.5194/acp-10-817-2010, 2010.

Giorgi, F. and Chameides, W. L.: Rainout lifetimes of highly soluble aerosols and gases as inferred from simulations with a general circulation model, J. Geophys. Res., 91, 14367-14376, 1986.

Gouw, J. A., Warneke, C., Parrish, D. D., Holloway, J. S., Trainer, M., and Fehsenfeld, F. C.: Emission sources and ocean uptake of acetonitrile $\left(\mathrm{CH}_{3} \mathrm{CN}\right)$ in the atmospherie, J. Geophy. Res., 108, 4329, doi:10.1029/2002JD002897, 2003.

Guenther, A., Karl, T., Harley, P., Wiedinmyer, C., Palmer, P. I., and Geron, C.: Estimates of global terrestrial isoprene emissions using MEGAN (Model of Emissions of Gases and Aerosols from Nature), Atmos. Chem. Phys., 6, 3181-3210, doi:10.5194/acp-63181-2006, 2006.

Harrigan, D. L., Fuelberg, H. E., Simpson, I. J., Blake, D. R., Carmichael, G. R., and Diskin, G. S.: Anthropogenic emissions during Arctas-A: mean transport characteristics and regional case studies, Atmos. Chem. Phys., 11, 8677-8701, doi:10.5194/acp11-8677-2011, 2011.

Hecobian, A., Liu, Z., Hennigan, C. J., Huey, L. G., Jimenez, J. L., Cubison, M. J., Vay, S., Diskin, G. S., Sachse, G. W., Wisthaler, A., Mikoviny, T., Weinheimer, A. J., Liao, J., Knapp, D. J., Wennberg, P. O., Kürten, A., Crounse, J. D., Clair, J. St., Wang, Y., and Weber, R. J.: Comparison of chemical characteristics of 495 biomass burning plumes intercepted by the NASA DC-8 aircraft during the ARCTAS/CARB-2008 field campaign, Atmos. Chem. Phys., 11, 13325-13337, doi:10.5194/acp-1113325-2011, 2011.

Hegg, D. A., Warren, S. G., Grenfell, T. C., Doherty, S. J., Larson, T. V., and Clarke, A. D.: Source attribution of black carbon in arctic snow, Environ. Sci. Technol., 43, 4016-4021, doi:10.1021/es803623f, 2009.

Jacob, D. J., Crawford, J. H., Maring, H., Clarke, A. D., Dibb, J. E., Emmons, L. K., Ferrare, R. A., Hostetler, C. A., Russell, P. B., Singh, H. B., Thompson, A. M., Shaw, G. E., McCauley, E., Pederson, J. R., and Fisher, J. A.: The Arctic Research of the Composition of the Troposphere from Aircraft and Satellites (ARCTAS) mission: design, execution, and first results, Atmos. Chem. Phys., 10, 5191-5212, doi:10.5194/acp-10-5191-2010, 2010.

Koch, D. and Hansen, J.: Distant origins of Arctic black carbon: A Goddard Institute for Space Studies ModelE experiment, J. Geophys. Res., 110, D04204, doi:10.1029/2004JD005296, 2005.

Kondo, Y., Matsui, H., Moteki, N., Sahu, L., Takegawa, N., Kajino, M., Zhao, Y., Cubison, M. J., Jimenez, J. L., Vay, S., Diskin, G. S., Anderson, B., Wisthaler, A., Mikoviny, T., Fuelberg, H. E., Blake, D. R., Huey, G., Weinheimer, A. J., Knapp, D. J., and Brune, H.: Emissions of black carbon, organic, and inorganic aerosols from biomass burning in North America and Asia in 2008, Geophys. Res., 116, D08204, doi:10.1029/2010JD015152, 2011a.

Kondo, Y., Sahu, L., Moteki, N., Khan, F., Takegawa, N., Liu, X., Koike, M., and Miyakawa, T.: Consistency and traceability of black carbon measurements made by laser induced incandescence, thermal optical transmittance, and filter-based photoabsorption techniques, Aerosol Sci. Technol., 45, 295-312, $2011 b$.

Li, Q., Jacob, D. J., Yantosca, R. M., Heald, C. L., Singh, H. B., Koike, M., Zhao, Y., Sachse, G. W., and Streets, D. G.: A global three-dimensional model analysis of the atmospheric budget of $\mathrm{HCN}$ and $\mathrm{CH}_{3} \mathrm{CN}$ : Constraints from aircraft and ground measurements, J. Geophys. Res., 108, 8827, doi:10.1029/2002JD003075, 2003.

Liang, Q., Rodriguez, J. M., Douglass, A. R., Crawford, J. H., Olson, J. R., Apel, E., Bian, H., Blake, D. R., Brune, W., Chin, M., Colarco, P. R., da Silva, A., Diskin, G. S., Duncan, B. N., Huey, L. G., Knapp, D. J., Montzka, D. D., Nielsen, J. E., Pawson, S., Riemer, D. D., Weinheimer, A. J., and Wisthaler, A.: Reactive nitrogen, ozone and ozone production in the Arctic troposphere and the impact of stratosphere-troposphere exchange, Atmos. Chem. Phys., 11, 13181-13199, doi:10.5194/acp-11-13181-2011, 2011.

Liousse, C., Penner, J. E., Chuang, C., Walton, J. J., Eddleman, H., and Cachier, H.: A global three-dimensional model study of carbonaceous aerosols, J. Geophys. Res., 101, 19411-19432, 1996.

Maria, S. F., Russell, L. M., Gilles, M. K., and Mynenl, S. C. B.: Organic aerosol growth mechanisms and their climate-forcing implications, Science, 306, 1921-1924, 2004.

Matsui, H., Kondo, Y., Moteki, N., Takegawa, N., Sahu, L. K., Zhao, Y., Fuelberg, H. E., Sessions, W. R., Diskin, G., Blake, D. R., Wisthaler, A., and Koike, M.: Seasonal variation of the transport of black carbon aerosol from the Asian continent to the Arctic during the ARCTAS aircraft campaign, J. Geophys. Res., 116, D05202, doi:10.1029/2010JD015067, 2011a.

Matsui, H., Y. Kondo, N. Moteki, N. Takegawa, L. K. Sahu, M. Koike, Y. Zhao, H. E. Fuelberg, W. R. Sessions, G. Diskin, B. E. Anderson, D. R. Blake, A. Wisthaler, M. J. Cubison, and Jimenez, J. L.: Accumulation?mode aerosol number concentrations in the Arctic during the ARCTAS aircraft campaign: Long?range transport of polluted and clean air from the Asian continent, J. Geophys. Res., 116, D20217, doi:10.1029/2011JD016189, 2011b.

McNaughton, C. S., Clarke, A. D., Freitag, S., Kapustin, V. N., Kondo, Y., Moteki, N., Sahu, L., Takegawa, N., Schwarz, J. P., Spackman, J. R., Watts, L., Diskin, G., Podolske, J., Holloway, J. S., Wisthaler, A., Mikoviny, T., de Gouw, J., Warneke, C., Jimenez, J., Cubison, M., Howell, S. G., Middlebrook, A., Bahreini, R., Anderson, B. E., Winstead, E., Thornhill, K. L., 
Lack, D., Cozic, J., and Brock, C. A.: Absorbing aerosol in the troposphere of the Western Arctic during the 2008 ARCTAS/ARCPAC airborne field campaigns, Atmos. Chem. Phys., 11, 7561-7582, doi:10.5194/acp-11-7561-2011, 2011.

Mian Chin, Diehl, T., Dubovik, O., Eck, T. F., Holben, B. N., Sinyuk, A., and Streets, D. G.: Light absorption by pollution, dust, and biomass burning aerosols: a global model study and evaluation with AERONET measurements, Ann. Geophys., 27, 3439-3464, doi:10.5194/angeo-27-3439-2009, 2009.

Moore, R. M.: Dichloromethane in North Atlantic waters, J. Geophys. Res., 109, C09004, doi:10.1029/2004JC002397, 2004.

Moteki, N. and Kondo, Y.: Effects of mixing state on black carbon measurements by laser?induced incandescence, Aerosol Sci. Technol., 41, 398-417, doi:10.1080/02786820701199728, 2007.

Pan, L., Edwards, D. P., Gille, J. C., Smith, M. W., and Drummond, J. R.: Satellite remote sensing of tropo- spheric $\mathrm{CO}$ and $\mathrm{CH}_{4}$ : Forward model studies of the MOPIT- Tinstrument, Appl. Optics, 34, 6976, doi:10.1364/AO.34.006976, 1995.

Paris, J.-D., Stohl, A., Nédélec, P., Arshinov, M. Yu., Panchenko, M. V., Shmargunov, V. P., Law, K. S., Belan, B. D., and Ciais, P.: Wildfire smoke in the Siberian Arctic in summer: source characterization and plume evolution from airborne measurements, Atmos. Chem. Phys., 9, 9315-9327, doi:10.5194/acp-9-9315-2009, 2009.

Petrenko, M., Kahn, R., Chin, M., Soja, A., Kucsera, T., and Harshvardhan: The use of satellitemeasured aerosol optical depth to constrain biomass burning emissions source strength in the global model GOCART, J. Geophys. Res., 117, D18212, doi:10.1029/2012JD017870, 2012.

Pommier, M., Law, K. S., Clerbaux, C., Turquety, S., Hurtmans, D., Hadji-Lazaro, J., Coheur, P.-F., Schlager, H., Ancellet, G., Paris, J.-D., Nédélec, P., Diskin, G. S., Podolske, J. R., Holloway, J. S., and Bernath, P.: IASI carbon monoxide validation over the Arctic during POLARCAT spring and summer campaigns, Atmos. Chem. Phys., 10, 10655-10678, doi:10.5194/acp-1010655-2010, 2010.

Quennehen, B., A. Schwarzenboeck, J. Schmale, J. Schneider, H. Sodemann, A. Stohl, G. Ancellet, S. Crumeyrolle, and Law, K. S.: Physical and chemical properties of pollution aerosol particles transported from North America to Greenland as measured during the POLARCAT summer campaign, Atmos. Chem. Phys. Discuss., 11, 11771-11808, 2011.

Quinn, P. K., G. Shaw, E. Andrews, E.G. Dutton, T. Ruoho-Airola, and Gong, S. L.: Arctic haze: current trends and knowledge gaps, Tellus B, 59, 99-114, doi:10.1111/j.1600- 0889.2006.00238.x, 2007.

Quinn, P. K., Bates, T. S., Baum, E., Doubleday, N., Fiore, A. M., Flanner, M., Fridlind, A., Garrett, T. J., Koch, D., Menon, S., Shindell, D., Stohl, A., and Warren, S. G.: Short-lived pollutants in the Arctic: their climate impact and possible mitigation strategies, Atmos. Chem. Phys., 8, 1723-1735, doi:10.5194/acp8-1723-2008, 2008.

Raatz, W. E. and Shaw, G. E.: Long-Range Tropospheric Transport of Pollution Aerosols into the Alaskan Arctic, J. Appl. Meteorol., 23, 1052-1064, 1984.

Rahn, K. A.: Relative importances of North America and Eurasia as sources of arctic aerosol, Atmos. Environ., 15, 1447-1455, 1981.

Rienecker, M. M., Suarez, M. J., Todling, R., Bacmeister, J., Takacs, L., Liu, H.-C., Gu, W., Sienkiewicz, M., Koster, R. D., Gelaro, R.,
Stajner, I., and Nielsen, E.: The GEOS-5 Data Assimilation System - Documentation of Versions 5.0.1, 5.1.0, and 5.2.0. Technical Report Series on Global Modeling and Data Assimilation 104606, v27, 2008.

Rienecker, M. M., Suarez, M. J., Gelaro, R., Todling, R., Bacmeister, J., Liu, E., Bosilovich, M. G., Schubert, S. D., Takacs, L.,Kim, G. K., Bloom, S., Chen, J., Collins, D., Conaty, A., da Silva, A., Gu, W., Joiner, J., Koster, R. D., Lucchesi, Andrea Molod, A., Owens, T., Pawson. S., Pegion, P., Redder, C. R., Reichle, R., Robertson, F. R., Ruddick, A. G., Sienkiewicz, M., and Woollen, J.: MERRA: NASA's Modern-Era Retrospective Analysis for Research and Applications, J. Climate, 24, 3624-3648, 2011.

Sachse, G. W., Hill, G. F., Wade, L. O., and Perry, M. G.: Fast response, high precision carbon monoxide sensor using a tunable diode laser absorption technique, J. Geophys. Res., 92, 20712081, 1987.

Shaw, G. E.: The Arctic haze phenomenon, B. Am. Meteorol. Soc., 76, 2403-2413, 1995.

Shindell, D. T., Chin, M., Dentener, F., Doherty, R. M., Faluvegi, G., Fiore, A. M., Hess, P., Koch, D. M., MacKenzie, I. A., Sanderson, M. G., Schultz, M. G., Schulz, M., Stevenson, D. S., Teich, H., Textor, C., Wild, O., Bergmann, D. J., Bey, I., Bian, H., Cuvelier, C., Duncan, B. N., Folberth, G., Horowitz, L. W., Jonson, J., Kaminski, J. W., Marmer, E., Park, R., Pringle, K. J., Schroeder, S., Szopa, S., Takemura, T., Zeng, G., Keating, T. J., and Zuber, A.: A multi-model assessment of pollution transport to the Arctic, Atmos. Chem. Phys., 8, 5353-5372, doi:10.5194/acp-85353-2008, 2008.

Shinozuka, Y., Redemann, J., Livingston, J. M., Russell, P. B., Clarke, A. D., Howell, S. G., Freitag, S., O’Neill, N. T., Reid, E. A., Johnson, R., Ramachandran, S., McNaughton, C. S., Kapustin, V. N., Brekhovskikh, V., Holben, B. N., and McArthur, L. J. B.: Airborne observation of aerosol optical depth during ARCTAS: vertical profiles, inter-comparison and fine-mode fraction, Atmos. Chem. Phys., 11, 3673-3688, doi:10.5194/acp-11-36732011, 2011.

Shinozuka, Y. and Redemann, J.: Horizontal variability of aerosol optical depth observed during the ARCTAS airborne experiment, Atmos. Chem. Phys., 11, 8489-8495, doi:10.5194/acp-118489-2011, 2011.

Singh, H. B., Salas, L., Herlth, D., Kolyer, R., Czech, E., Viezee, W., Li, Q., Jacob, D. J., Blake, D., Sachse, G., Harward, C.N., Fuelberg, H., Kiley, C. M., Zhao, Y., and Kondo, Y.: In situ measurements of $\mathrm{HCN}$ and $\mathrm{CH} 3 \mathrm{CN}$ over the Pacific Ocean: source, sinks, and budgets, J. Geophys. Res., 108, 8795, doi:10.1029/2002JD003006, 2003.

Singh, H. B., Anderson, B. E., Brune, W. H., Cai, C., Cohen, R. C., Crawford, J. H., Cubison, M. J., Czech, E. P., Emmons, L., Fuel- berg, H. E., Huey, G., Jacob, D. J., Jimenez, J. L., Kaduwela, A., Kondo, Y., Mao, J., Olson, J. R., Sachse, G. W., Vay, S. A., Wein- heimer, A., Wennberg, P. O., and Wisthaler, A.: Pollution influences on atmospheric composition and chemistry at high northern latitudes: Boreal and California for- est fire emissions, Atmos. Environ., 44, 4553-4564, doi:10.1016/j.atmosenv.2010.08.026, 2010.

Soja, A. J., Stocks, B., Maczek, P., Fromm, M., Servranckx, R., Turetsky, M., and Benscoter, B.: ARCTAS: the perfect smoke, The Canadian Smoke Newsletter, 2e7, 2008. 
Stohl, A.: Characteristics of atmospheric transport into the Arctic troposphere, J. Geophys Res., vol.111, D11306, doi:1029/2005JD006888, 2006.

Stohl, A., Berg, T., Burkhart, J. F., Fjæraa, A. M., Forster, C., Herber, A., Hov, Ø., Lunder, C., McMillan, W. W., Oltmans, S., Shiobara, M., Simpson, D., Solberg, S., Stebel, K., Ström, J., Tørseth, K., Treffeisen, R., Virkkunen, K., and Yttri, K. E.: Arctic smoke - record high air pollution levels in the European Arctic due to agricultural fires in Eastern Europe in spring 2006, Atmos. Chem. Phys., 7, 511-534, doi:10.5194/acp-7-511-2007, 2007.

Streets, D. G., Yan, F., Chin, M., Diehl, T., Mahowald, N., Schultz, M., Wild, M., Wu, Y., and Yu, C.: Anthropogenic and natural contributions to regional trends in aerosol optical depth, 1980-2006, J. Geophys. Res., 114, D00D18, doi:10.1029/2008jd011624, 2009.

Wang, Q., Jacob, D. J., Fisher, J. A., Mao, J., Leibensperger, E. M., Carouge, C. C., Le Sager, P., Kondo, Y., Jimenez, J. L., Cubison, M. J., and Doherty, S. J.: Sources of carbonaceous aerosols and deposited black carbon in the Arctic in winter-spring: implications for radiative forcing, Atmos. Chem. Phys., 11, 1245312473, doi:10.5194/acp-11-12453-2011, 2011.

Warneke, C., Bahreini, R., Brioude, J., Brock, C. A., de Gouw, J. A., Fahey, D. W., Froyd, K. D., Holloway, J. S., Middlebrook, A., Miller, L., Montzka, S., Murphy, D. M., Peischl, J., Ryerson, T. B., Schwarz, J. P., Spackman, J. R., and Veres, P.: burning in Siberia and Kazakhstan as an important source for haze over the Alaskan Arctic in April 2008, Geophys. Res. Lett., 36, L02813, doi:10.1029/2008GL036194, 2009.
Warneke, C., Froyd, K. D., Brioude, J., Bahreini, R., Brock, C. A., Cozic, J., de Gouw, J. A., Fahey, D. W., Ferrare, R., Holloway, J. S., Middlebrook, A. M., Miller, L., Montzka, S., Schwarz, J. P., Sodemann, H., Spackman, J. R., and Stohl, A.: An important contribution to springtime Arctic aerosol from biomass burning in Russia, Geophys. Res. Lett., 37, L01801, doi:10.1029/2009GL041816, 2010.

Weber, R. J., Orsini, D., Wang, B., Scheuer, E., Talbot, R. W., Dibb, J. E., Seid, G. K., DeBell, L., Mauldin, R. L., Kosciuch, E., Cantrell, C., and Eisele, F.: Investigations into free tropospheric new particle formation in the central Canadian arctic during the winter/spring transition as part of TOPSE, J. Geophys. Res., 108, 8357, doi:10.1029/2002JD002239, 2003.

Wesely, M. L.: Parameterization of surface resistance to gaseous dry deposition in regional-scale numerical models, Atmos. Environ., 23, 1293-1304, 1989.

Wisthaler, A., Hansel, A., Crutzen, P., and Dickerson, R.: Organic trace gas measurements by PTR-MS during INDOEX 1999, J. Geophys. Res., 107, 8024, doi:10.1029/2001JD000576, 2002.

Yuan, T., Remer, L. A., Bian, H., Ziemke, J. R., Albrecht, R., Pickering, K. E., Oreopoulos, L., Goodman, S. J., Yu, H., and Allen, D. J.: Aerosol indirect effect on tropospheric ozone via cloud lightning, J. Geophy. Res., 117, D18213, doi:10.1029/2012JD017723, 2012. 